\title{
Traditional Governance and Innovative Strategies in Italian Family SMEs: Evidence from Tuscany
}

\author{
Mariacristina Bonti ${ }^{1} \&$ Enrico Cori ${ }^{2}$ \\ ${ }^{1}$ Department of Economics and Management, University of Pisa, Italy \\ ${ }^{2}$ Department of Management, Polytechnic University of Marche, Ancona, Italy \\ Correspondence: Enrico Cori, Department of Management, Polytechnic University of Marche, Ancona, Italy.
}

Received: November 14, 2017

Accepted: December 13, 2017

Online Published: January 8, 2018

doi:10.5539/ibr.v11n2p103

URL: https://doi.org/10.5539/ibr.v11n2p103

\begin{abstract}
Governance in family businesses is a relatively recent research topic in the field of management studies. Much research has sought to shed light on the factors that shape the relationship between governance structures and corporate strategies. Nevertheless, very little research has specifically addressed the relationships between the configuration of the Board of Directors and the firm's willingness to carry out innovative strategies. Our study aims to shed light on the relationship between the corporate governance structures and the pace of innovation within family SMEs. Evidence from three family-owned SMEs located in Tuscany (Italy) highlights that a traditional type of governance structure can co-exist with the search for innovative strategies and that the intensity of the innovation processes may not be tied to the Board's composition.
\end{abstract}

Keywords: family SMEs, innovation, governance, Board of Directors

JEL Code: L22, L25, M10

\section{Introduction}

Governance in family businesses is a relatively recent research topic in the field of management studies. Initially, theoretical and empirical research focused mainly on the differences between family and non-family businesses as regards governance choices, organizational behavior, and performance. Later, the analysis went further, to better understand the peculiar characteristics of corporate governance in family businesses, often with a normative aim.

The topic of innovation is no less considered in the literature on family business. This area was mainly addressed by considering two aspects: the impact that family involvement in property and management can have on the innovative capacity of firms and, for SMEs, both the limitations deriving from smaller sized businesses, as well as the opportunities for pursuing innovation through cooperation and networking strategies.

Much research has sought to shed light on the factors that shape the relationship between governance structures and corporate strategies. Among these, the influence of the generational change on the degree of homogeneity/heterogeneity of ownership (Kellermanns \& Eddleston, 2006) and the issue of the professionalization of the family management (Hall \& Nordqvist, 2008; Dekker, Lybaert, Steijvers, \& Depaire, 2015) seem to hold special meaning. Moreover, a number of studies have investigated the impact of governance structures on innovation (Hoskisson, Hitt, Johnson, \& Grossman, 2002), as well as the impact of the composition of the Board of Directors (hereafter BoD) on internationalization (Calabrò, Mussolino, \& Huse, 2009; Arregle, Naldi, Nordqvist, \& Hitt, 2012; Segaro, 2012; Majocchi \& Strange, 2012; Corsi \& Prencipe, 2015) and on the firm's performance (Kouki \& Guizani, 2015; Gonzàlez-Cruz \& Cruz-Ros, 2016).

Nevertheless, very little research has specifically addressed the relationships between the configuration of the BoD and the firm's willingness to carry out innovation strategies. Some scholars have just recently called for the development of this area of inquiry (De Massis, Chirico, Kotlar \& Naldi, 2014; Chrisman, Chua, De Massis, Frattini \& Wright, 2015), arguing that the configuration of the firm's governance structure may influence its engagement in innovation activities.

Our study aims to shed light on the relationship between the corporate governance structures and the pace of innovation within family SMEs. We wonder if and to what extent the governance structure in family SMEs, with 
particular reference to the $\mathrm{BoD}$, can influence their innovative capacity and the implementation of innovation strategy.

The analysis of three family-owned SMEs located in Tuscany (Italy) offers some insights on this debate. We focus on the composition and the dynamics of the $\mathrm{BoD}$, as regards the presence of non-family members, the ratio of family/non-family members, and their role in co-determining the innovative pace of the firm.

Evidence from the three firms highlights that a traditional type of governance structure - which does not provide for the participation of members external to the family on the Board - can co-exist with the search for innovative strategies and that the intensity of the innovation processes may not be tied to the Board's composition. In sum, our findings question the results of previous studies, as regards the existence of a "best configuration" of the $\mathrm{BoD}$ for pursuing the firm's innovation.

In the following paragraph we briefly illustrate the theoretical background; in section 3 we outline the research objectives and methodology; in section 4 we offer a brief description of the firms analyzed; in section 5 we outline and debate the results of our analysis; and lastly, in section 6 we draw some conclusion and point out the main limitations of the research.

\section{Theoretical Background}

\subsection{Governance Assets in Family SMEs}

Studies on governance in family businesses have evolved over time along some main paths. Research on the impact of governance structures and mechanisms on business performance developed towards the end of the 1980s (Pieper, 2003) although the focus on family SMEs is much more recent. A stream of literature pointed out the need for a dual structure of governance for the family firm: one for managing the family, and one for managing the business. At the same time, these studies focused on the characteristics of the BoD and suggested some guidelines for its establishment.

According to Miller-Le Breton Miller (2005) the position of Board member should be attained through the acquisition of some specific skills, and not simply by virtue of inheritance. Board members should manifest different but complementary skills; moreover, they should not be merely the expression of the family (diverse families or family branches), thus ensuring a balance between family and business perspectives.

The importance of non-family members' involvement inside the Board - the so-called "outsiders" - is one of the most oft-discussed topics in the literature (Ward, 1988, 1989; Johannisson \& Huse, 2000; Gabrielsson \& Huse, 2005; Voordeckers, Van Gils \& Van den Heuve, 2007), yet academic research is still far from proving their positive impact on the firm's performance (Bettinelli, 2011; Nordqvist, Sharma, \& Chirico, 2014). Outsiders can promote a better awareness of managerial issues, they can provide alternative information, experience, perspectives, and they can de velop a greater ability to interpret changes in the environment (Schulze, Lubatkin, \& Dino, 2003; Bammens, Voordeckers \&Van Gils, 2011). Moreover, they can contribute to resolving internal conflicts and to achieving consensus within the $\mathrm{BoD}$ (Bammens et al., 2011). This helps protect stakeholders from opportunistic behaviors; it also allows them to gain legitimacy and to have access to external or network resources (Schwartz \& Barnes, 1991; Johannisson \& Huse, 2000). Some evidence exists as regards the positive impact of outsiders on innovation (Zahra \& Pearce, 1989), on internationalization (Calabró \& Mussolino, 2011; Chen, Hsu, \& Chang, 2014), and on financial performance (Gubitta \& Pittino, 2009; Dekker et al, 2015). At the same time, since outsiders find themselves working in an "emotional arena" (Van den Heuvel, Van Gils, \& Voordeckers, 2006), they may appear to be "strangers" due to their lack of specific knowledge about the firm's history and environment which can be detrimental to performance if these non-family Board members are not aligned with the goals, the values, and the expectations of the family members.

On the contrary, the prevalence of inside members increases the risk of "partiality" and a "closed" outlook in the analysis of the firm's environment, which can potentially lead to not seizing opportunities or to not recognizing problems and threats. Objectives such as maintaining family control, financial independence, family employment, and harmony within the firm tend to overshadow growth and innovation goals.

It is widely acknowledged that the Board can play two main roles: a control role and a service role (Huse, 2007). In family firms, these roles change along with the family life-cycle (Lynall, Golden, \& Hillman, 2003; Filatotchev, Toms, \& Wright, 2006; Van den Heuvel et al., 2006; Pardo del Val, 2009; LeBreton-Miller \& Miller, 2013), and as a consequence of succession processes (i.e., number of generational passages and number of descendants involved).

When property and management overlap and the firm's vision is shared, service roles can bring greater added-value. Given the generally low level of professionalization of family SMEs, it becomes important to be 
able to rely on advice and support for strategic decision-making, as well as on valuable relational networks (Gabrielsson \& Winlund, 2000; Golden \& Zajac 2001; Huse 2007; Zahra \& Pearce 1989; Daily, Dalton, \& Cannella, 2003). Outside Board members can bring managerial skills and networking abilities to the firm, thus compensating for the shortage of competences in family members and helping the firm sustain its orientation towards innovation. The development of internal learning processes from generation to generation (Klein, Shapiro, \& Young, 2005; Bonti \& Cori, 2011; Cori \& Bonti, 2014; Maseda, Itturalde, \& Arosa, 2015; Blanco-Mazagatos, de Quevedo-Puente, \& Delgado-García, 2016) may reduce the need for additional (and external) knowledge and abilities.

Control roles become significant especially after the first generational shift, when it is likely that more than one generation or more than one family branch is involved in the firm's governance and management. A clash of interests can often occur between the short-term orientation of some family members and the longer-term perspective of others (Vilaseca, 2002; Lumpkin \& Brigham, 2011). In these cases (Ward, 1997; Van den Heuvel et al., 2006), the Board is expected to play a role of control and to mediate among different interests (Gabrielsson $\&$ Huse, 2005), especially when conflict intensifies and seems to preclude a consensus (Jehn, 1995).

\subsection{Innovation as a Strategy in Family SMEs}

Innovation is the lever by which all businesses can capture, explore, and exploit business opportunities. Empirical research has highlighted that some distinctive features of family SMEs may either foster or inhibit innovation (De Massis et al., 2015). This means that it is not possible to state, a priori, if family firms are more or less innovative than non-family businesses (Craig \& Dibrell, 2006; Llach \& Nordqvist, 2010; Carnes \& Ireland, 2013). Among the favorable conditions for innovation, the importance of the family's values and of the inheritance to be conveyed, the prevalence of a multi-generational perspective, the lower levels of formalization, the presence of "patient" capital, as well as the alignment of ownership and management interests are often identified. (Le Breton-Miller \& Miller, 2006; Kellermanns \& Eddleston, 2006).

At the same time, a low propensity for and unwillingness to take risks, the overlap of family ownership and control (Schulze et al., 2003), as well as the desire to not open management to non-family members are factors that can exert a braking force on the decision to undertake innovation pathways (Chrisman et al., 2015). By leveraging mainly on internal resources, family SMEs limit their interactions with the outside environment, a source of new knowledge, information, and ideas. In that sense, the presence of only family members on the Board may not only deprive the company of the availability of new skills and experiences, but could also inhibit or prevent the exchange and renewal of competences already held by family members. Conservative and defensive behaviors, strongly anchored to an "old" way of managing the firm, tend to have the upper hand (Carney, 2005), risking to compromise the firm's longevity.

Intergenerational transitions may also influence the pace of innovation within the firm, through the redesign of governance structures (e.g. the Board's composition), as a result of different degrees of family involvement (Maseda et al., 2015; Blanco-Mazagatos et al., 2016). Different governance structures - presence of family and/or non-family members, number of generations and/or family branches, types of roles on the Board, and so on (Gómez-Mejía, Haynes, Núñez-Nickel, Jacobson, \& Moyano-Fuentes, 2007; Le Breton-Miller \& Miller, 2006) - can compromise the firm's ability to have multiple and different perspectives. These, in turn, can affect some critical factors in fostering innovation: the degree of renewal of strategic objectives, the attitude towards risk-taking, and the temporal horizon of investments (Carnes \& Ireland, 2013; Cucculelli, Le Breton-Miller, \& Miller, 2016).

The studies that have been focused on family firms, in an effort to identify those factors that influence their innovative capacity (Li \& Daspit, 2016, Gómez-Mejía et al., 2007), have proposed the idea of the existence of a best innovation strategy. We, instead, suggest that each family firm should be able to identify an innovative path that is consistent with the firm's features and context. The efforts that firms make to promote product/process innovation do not necessarily consist of leaps forward, or mimetic behaviors aimed at replicating existing models Rather, firms should foresee an evolutionary path towards a new equilibrium where innovation choices, cultural traits, and the other distinctive features of the family-owned firm are mutually consistent.

\section{Research Objectives, Methodology, and Data Collection}

The aim of our research was to assess whether and to what extent the dynamics of the governance structures in family SMEs may affect their innovation paths. Specifically, we aimed to shed light on the relationship between the dynamics of the BoD and other governing bodies, the ways in which the company acquires or gains access to new knowledge, and the degree of innovation in product/market strategies. 
Starting from mainstream literature on the governance structures in the family-owned SMEs, the results of our research may contribute to a theoretical advancement in the understanding of the relationship between choices concerning the governance structures and the innovation strategies of family-owned businesses. We believe that the findings may allow a process of analytical generalization (Eisenhardt, 1989), by providing new insights regarding the impact of governance structures on SMEs' innovation strategies.

We carried out a multiple case-study, in the logic of replication (Yin, 2009; Pauwels \& Matthyssens, 2004; Eisenhardt \& Graebner, 2007; De Massis \& Kotlar, 2014). The analysis is exploratory in nature, since we are interested in studying how choices concerning the governance structures affect the firms' innovation processes. Moreover, it has a longitudinal feature, as we observed changes in the governance structures and in the firm's portfolio that occurred in the time period of 2010-2016.

We investigated three family-owned SMEs, located in the region of Tuscany. The desire to consider a territory that is sufficiently homogeneous as regards entrepreneurial culture and paths of industrial development led us to circumscribe our analysis to this geographical area.

The companies were selected on the basis of the following criteria: small- and medium-sized (EU range); homogeneous entrepreneurial culture; third entrepreneurial generation or beyond; ownership still held by the founder's family; same product niche as at the start of the company; availability of the current entrepreneur.

The three firms belong to the following industries: clothing-textile, gold-beating (gold leaf), and fired bricks (cotto, "cooked" as in fired brick, in Italian). The first one shows a low concentration ratio (5\% for textile, $12 \%$ for clothing), while the other two industries highlight a notably higher ratio (Istat, 2014). As regards the extension of the respective markets, for one textile firm (Lanificio Cangioli 1859, hereafter "the Lanificio") the principle market of reference is Italy, notwithstanding increasing exports; while for the other two companies (Giusto Manetti Battiloro, hereafter "the Battiloro", and Sannini Impruneta) the foreign market absorbs a prevalent share of turnover. The firm size ranges from 20 to 250 employees, while the turnover category ranges from 4.5 to 25 million euros. For all these reasons, they offer interesting food for thought. This data is summed up in Table 1, below.

Table 1. Main features of the sample

\begin{tabular}{|l|c|c|c|c|c|c|}
\hline \multicolumn{1}{|c|}{ Firm } & Industry & $\begin{array}{c}\text { Employees } \\
\mathbf{( 2 0 1 6 )}\end{array}$ & $\begin{array}{c}\text { Sales } \\
\mathbf{( 2 0 1 6 ,} \\
\mathbf{M ~} \mathbf{\epsilon})\end{array}$ & $\begin{array}{c}\text { Main } \\
\text { market }\end{array}$ & $\begin{array}{c}\text { Year of } \\
\text { establishment }\end{array}$ & $\begin{array}{c}\text { Number of } \\
\text { generations }\end{array}$ \\
\hline Lanificio Cangioli 1859 & clothing-textile & $21-50$ & $10-25$ & $\begin{array}{c}\text { national } \\
\text { (italy) }\end{array}$ & 1859 & 5 \\
\hline Sannini Impruneta & $\begin{array}{c}\text { fired bricks } \\
\text { ("cotto) }\end{array}$ & $21-50$ & $2-5$ & foreign & 1910 & 4 \\
\hline Giusto Manetti Battiloro & gold-beating & $101-250$ & $10-25$ & foreign & 1820 & 6 \\
\hline
\end{tabular}

Source: https://it.kompass.com and data collected through direct interviews

The research was carried out by using both primary and secondary data. Primary data was collected through semi-structured face-to-face interviews with one member of the firm owner's family currently involved in the entrepreneurial activity. The interviews (two for each company) were conducted between early 2009 and mid 2016; they lasted from one and half to two hours, and were tape-recorded and transcribed. Field notes were also collected.

In the first interview (2009-2010), the entrepreneurs were given free rein to narrate their family firm's history. The purpose was to obtain a very complete picture of the following items: the firm's strategic-competitive position, the evolutionary paths followed since its foundation, the knowledge/skills sustaining the competitive edge, and the most meaningful features concerning governance and organizational structure.

The second interview (2016) was mainly aimed at verifying the occurrence of any change in the governance structure in the last few years and at analyzing the more recent management choices concerning product innovation and market strategy.

Secondary data consisted of documents provided by the entrepreneurs themselves, information from the companies' websites, and press releases. Notwithstanding the fact that the relevance varied from one firm to another, these sources of information were able to meaningfully strengthen the "story" that we had been told during the interviews. 


\section{The Cases in Short}

As mentioned above, the three cases were selected based on some common features, such as size, company culture, ownership, having passed into the hands of the third (or greater) entrepreneurial generation, and a careful balance between tradition and innovation. Nevertheless, the three firms also display some specificities related to their belonging to different industries and to their innovating at quite different paces; they also varied in type of product and market strategies. In the process of investigation, we used a replication logic. We began by analyzing the relationship between governance and innovation strategies within the firm that seemed to be characterized by a slower innovation pace; then, we continued with the firm that showed a notable but not very fast pace, and lastly, we investigated the firm in which we could detect a faster innovation pace. Below, we succinctly describe the peculiarities of each of the three firms, in terms of evolutionary path, products, and markets, based on their competitive edge and recent meaningful strategic changes.

\section{Lanificio Cangioli 1859}

The founder Vincenzo Cangioli started his entrepreneurial activity in 1859 with a pharmacy and a textile workshop. He worked as an upholsterer and was also a buyer, designer, and the market manager of this woolen fabric product. From the second generation on, the business began the production of wool fabrics. In the 1990s they steered the company towards a high degree of innovation, high flexibility, and high-quality standards, through the strengthening the vertical industrial structure. Thanks to these changes, the Lanificio has brilliantly overcome the period of crisis that deeply affected the textile district of Prato, in northern Tuscany where the company is headquartered. Two brothers, representing the fifth generation of owners, are presently at the helm of this company; they share equally in the governance and management of the company.

The firm's distinctive competences are identified first and foremost in the technical knowledge of its owners and employees and in the creativity of the product. Along with some standardized lines, the company also offers customized lines, developing special designs and colors in cooperation with the client. The pursuit of creativity characterizes the design of the collections, both for men and women; these can achieve a modern look with classic fabrics, as well as a classic look with fabrics having an innovative composition of fibers.

\section{Sannini Impruneta}

This company was set up in 1910, following a transformation of the original artisanal trade into an industrial one. Its founder was previously a silk merchant. Today, Sannini Impruneta, located just a few kilometers from Florence, is one of the most well-known and long-lived companies in the industrial production of terracotta paving tiles and façades (curtain walls). The production consists of a wide range of floor and wall tile products for the building industry. The search for innovative designs showcases the artistic and architectural values of terracotta in a modern and original way.

The classic lines of the hand-made cotto were integrated over time with the production of pavings and façades, both made through automated processes. The continuous study of new materials is combined with a particular attention to the sustainability of the production process. In addition to its standard products, the company is able to develop custom solutions for projects that are jointly developed with architects and designers. In the last few years, a further innovation, Terraoro, came about as the result of a joint project with the Battiloro.

The product not only continues the Renaissance tradition in the renown Florentine style, but continues to maintain the high quality of its raw materials and workmanship. This, together with the managerial capacity built around its productive skills, all constitute the basic criteria for the firm's competitive edge. The company, now in its fourth entrepreneurial generation, is managed by one of the three descendants of the founder; the BoD has a very simple configuration, including two members of the same branch of the owner family.

\section{Giusto Manetti Battiloro}

The origins of the company go back to 1820 , when the founder first transformed the craftsman's gilding workshop, which was already active in Florence for two generations, into a "gold-beating" trade. Following repeated operations of acquisition and smelting, mainly during the fourth generation of owners, the Battiloro became one of the few companies in the sector able to operate on the global market. Currently, the company has its headquarters and main production plant in Florence; two subsidiaries are located in Spain and Poland. It is presently managed by two branches of the entrepreneurial family; both parts equally sharing the governing and managerial roles.

The quasi-artisanal character of its production process, combined with managerial competence which evolved in the commercial and administrative areas, constitutes the source of the company's competitive advantage still today. 
Alongside its traditional productions, gold leaf and gilding products for artistic decoration and restoration, the company has recently strengthened its presence in other markets, such as interior design, furniture and furnishings accessories. Moreover, new product lines have been introduced: Terraoro, Gold Chef (edible gold), and Beauty Gold (gold for cosmetics).

\section{Findings}

\subsection{Innovation Strategies}

In the 2010-2016 time period, the three firms showed a notable ability to face environmental challenges and to overcome the world economic crisis. Changes observed in product and market strategies have ne ver contradicted the consolidated orientation of the firm, that is, the search for a careful balance between tradition and inno vation. However, the push towards innovation in the three firms has been dissimilar, as was supposed after the analysis of the available documents.

For the purposes of this study, we considered product innovations as a major change in the firm's portfolio. In accordance with Matzler et al. (2015), we took the number of new products as an indicator of the innovation pace. Moreover, we took into account the entrance into new markets and market niches that considerably modified the firm's competitive arena.

Our inquiry revealed that the Lanificio has been characterized by a moderate innovation pace, primarily concerning production lines. Changes that occurred during the period of observation show an emergent differentiation strategy, aimed at enforcing the presence of the firm in the high-end market segment, continuing the path started in the 90s. Such a differentiation strategy did not give rise to any specific need for new competences, but rather, a recombination of those already held by the firm.

"With the help of a consultant and also thanks to the product skills developed in the meantime, Sabina and I decided to work on lighter fabrics (combed wool yarn), to wear in all seasons. But the consultant was not a creative designer, so we decided (...) to look for a young man who could fit the company's needs" (Vincenzo Cangioli, 4-7-2016)

On the contrary, the Battiloro has maintained a fast innovation pace, concerning both the brand renewal and the penetration into new markets. Gold leaf has gradually been used in new kinds of products and for different consumer targets, exploring new businesses opportunities, even far from the traditional domain of the firm.

The innovations carried out during the observation period seem to sometimes indicate differentiation, looking at the manufacturing technologies and the enlargement of the originally developed market, and sometimes diversification, considering the entrance into emergent markets, such as cosmetics and the food industry, in a logic of exploration. Acase in itself is represented by the launch of Terraoro.

"The idea of putting together brick and gold leaf (for the decoration of luxury residences) is highly innovative and, at the same time, it combines two Tuscan artisan traditions. It also represents a strong discontinuity in terms of manufacturing process, being a completely hand-made product" (Niccolò Manetti, 12-4-2016)

Differentiation and diversification strategies required new competences, both technical and managerial. Indeed, the transition from semi-finished to finished products (for cosmetics and edible products) necessitated developing flexible know-how be able to produce gold leaf of different hardness, depending on the industry in which it is to be used. Moreover, the launch of Terraoro required a marked change in the management approach as well as in the firm's culture.

Lastly, the innovation pace at Sannini Impruneta can be classified at an intermediate level if compared to the other two firms. It has primarily consisted in the integration of "vertical" products (façades) with the traditional "horizontal" floor coverings (pavings), the main business since the foundation of the firm.

"Some of the most renowned architects have highlighted a new use of terracotta in the façade cladding of buildings, allowing further re-launching of a material that is highly versatile and rich in historical meanings" (Carlo Poccianti, 27-6-2016)

The idea of employing cotto for the façade of a building has quasi-automatically determined a wider variety of markets served; in particular, it opened good opportunities in the field of international government projects concerning building and infrastructures. Such changes in the firm's policy, while being traced back to a differentiation strategy, required the development of new competence, related to installation more than to the change and the upgrading of manufacturing techniques. Indeed, the mounting of façades requires much greater technical skills than laying tiles on a floor; this is due either to the vertical position itself or to the fact that in 
some buildings the cotto blocks rotate. Table 2, below, provides an overview of the main innovations concerning products and markets - undertaken by the firms during the period of analysis.

Table 2. Type and degree of innovation (2010-2016)

\begin{tabular}{|c|c|c|c|}
\hline Innovation strategies & Lanificio Cangioli 1859 & Sannini Impruneta & $\begin{array}{l}\text { Giusto Manetti } \\
\text { Battiloro }\end{array}$ \\
\hline new products & $\begin{array}{l}\text { Fabbrica (men's collection) } \\
\text { Ad hoc (high-end women's } \\
\text { collection) }\end{array}$ & Terraoro & $\begin{array}{l}\text { Terraoro } \\
\text { Chef gold } \\
\text { Beauty Gold }\end{array}$ \\
\hline new market niches & & $\begin{array}{l}\text { government projects } \\
\text { (railway stations, theaters, } \\
\text { roadway sound barriers...) }\end{array}$ & $\begin{array}{l}\text { furniture and furnishing } \\
\text { accessories }\end{array}$ \\
\hline $\begin{array}{l}\text { competences developed } \\
\text { (related to product } \\
\text { launching or market entry) }\end{array}$ & no & $\begin{array}{l}\text { technical (product } \\
\text { differentiation, façades } \\
\text { installation) }\end{array}$ & $\begin{array}{l}\text { technical (hand-made } \\
\text { products) \& managerial }\end{array}$ \\
\hline $\begin{array}{l}\text { degree of innovation in } \\
\text { product/market strategies }\end{array}$ & low & medium & high \\
\hline
\end{tabular}

Source: data collected through direct interviews

\subsection{Governance Structures}

Looking at the evolution of governance structures required going back some years before our interviews with the entrepreneurs. We investigated both the composition and the dynamics of the BoDs, as regards the presence of one or more family branches and of outside directors.

In all of the companies, we found only internal directors on their Board, which is what Schwartz and Barnes (1991) call an "all-family Board". Instead, the dynamics observed in connection with the last generational transition varied slightly across the firms, as summarized in Table 3 and described below.

Table 3. Type and dynamics of governing bodies

\begin{tabular}{|c|c|c|c|}
\hline Firm & Industry & Employees & Sales \\
\hline composition of the Board: & 2 & 2 & 6 \\
\hline number of family members & only family members & only family members & only family members \\
\hline number of non-family members & 0 & 0 & 0 \\
\hline number of family branches & 1 & 1 & 2 \\
\hline $\begin{array}{l}\text { change in number/type of } \\
\text { members (2010-2016) }\end{array}$ & no & no & no \\
\hline $\begin{array}{l}\text { last change in the composition } \\
\text { of the Board }\end{array}$ & $\begin{array}{l}2003 \\
\text { (exit of the other } \\
\text { family branch) }\end{array}$ & $\begin{array}{c}1999 \\
\text { (exit of the previous } \\
\text { generation and of the other } \\
\text { family branch) }\end{array}$ & $\begin{array}{c}2009 \\
\text { (exit of the previous } \\
\text { generation) }\end{array}$ \\
\hline other governing bodies & no & $\begin{array}{l}\text { no formal body; } \\
\text { frequent informal meetings } \\
\text { with all family shareholders }\end{array}$ & no \\
\hline
\end{tabular}

Source: data collected through direct interviews

The Lanificio simplified its governance structure because one of the two family branches decided to leave the family business. It left both control and management roles, after a period of difficult co-management by the two family branches at the helm of the company. The BoD is the only governing body and its configuration is considered suitable to the current state of the business; no need for higher formalization is perceived. Possible changes will occur only in perspective, given that the entrepreneurial family is currently evaluating to the possibility of enlarging the proprietary base as it is not clear whether the forthcoming generation will be interested in carrying on the family business. However, no change in the governance structure is hypothesized in relation to innovation strategy or to the need to strengthen competences held by the company.

"Our governance structure is characterized by clear roles, results show that this way is right (...); we decided to share tasks among us informally, no formal proxies have been decided. However, we need to start thinking of an exit strategy (as regards both management and control); if we find the way to enlarge the 
proprietary base (the issue of a higher degree of formalization) should be faced" (Vincenzo Cangioli, 4-7-2016)

The dynamics of governance shown by the Battiloro during the last generational change have been quite different, notwithstanding the fact that family structures here and in the Lanificio are similar. In the gold-beating company the transition from the fifth to the sixth entrepreneurial generation took place in two steps, within a decade. In the 80s the members of one family branch sat on the Board and assumed control and management responsibilities; they were followed by the members of the other family branch at the beginning of the 90s. Thus, the composition of the BoD showed a notable enlargement, due to the inclusion of all the members of the sixth generation. This, jointly with intra-generational differences concerning the entrepreneurial orientation, gave rise to some conflicts and resulted in an uneasy cohabitation between the two branches.

This situation notwithstanding, no significant change has been implemented up to now, perhaps to avoid taking any step that could throw off a precarious state of equilibrium. The only change that was made concerns last member of the previous generation leaving the Board, but this is not considered very meaningful to the decisions taken later in the company. Howe ver, the entrepreneur we interviewed explicitly stated his wish to shape the Board differently.

"If the whole company were mine, I would have already integrated (the current configuration of the Board) with a lawyer and a tax consultant, leaving only two members for each family branch." (Niccolò Manetti, 12-4-2016)

Finally, the Sannini Impruneta company shows a fairly simple and stable composition of the BoD which includes only two members from the same family branch. There had been a third member who retired during the $90 \mathrm{~s}$ and was never replaced. To balance this very simple configuration, informal meetings with all the family shareholders take place regularly; this does not, however, lead to the formation of new governing bodies. The stability of the governance structure is considered a strength that can help in overcoming the current phase of uncertainty. Changes in the Board can be envisaged only in case the company would decide to integrate with an industrial partner; this would allow the firm to internalize competences related to the installation of façades.

"We do not necessarily consider as inappropriate that the Board has not changed its composition for a long time. Rather, we intentionally decided to stay (in the BoD) to walk together to this juncture" (Carlo Poccianti, 27-6-2016)

\subsection{In Search of New Competences}

Evidence from the three firms shows that innovation strategies are not supported by changes in the governance structures. No change in the Board's composition occurred contextually or in advance with respect to the decisions concerning product innovation or market expansion. Neither was there a phase of innovation generation fostered by a change in the governance structure, nor was there a phase of implementation supported by new competences brought in by new Board members. If this situation seems reasonable in the case of the Lanificio, where innovation can be regarded as "incremental" and does not require developing new knowledge and skills, it calls for an alternative explanation when reflecting on the innovation processes carried out by the Battiloro and Sannini Impruneta. In the first case, the innovation strategy demanded only new technical competences, while in the second case, in order to implement the innovation process, both technical and managerial skills required upgrading. Therefore, we asked the entrepreneurs how their firms have succeeded in acquiring, or accessing competences perceived as necessary following the implementation of innovation strategies.

In the case of Sannini Impruneta, the competences needed for entering the business of curtain walls were developed in two different ways. On the one hand, an interpersonal network was developed by the current entrepreneur, in order to imagine new ways of employing cotto as a vertical covering.

"Tailor-made production is our strength: we work with famous architects and each of them proposes something different ... because they are great innovators. the idea of using terracotta in the façades was by Renzo Piano" (Carlo Poccianti, 27-6-2016)

The projects carried out in collaboration with them showcased a new use of terracotta on the façade of important buildings, thus giving rise to a strategy of re-launching this material. On the other hand, an external manager coming from the marble-cutting industry was hired, in order to build technical skills and to find technical solutions for the installation of façades. He is currently involved in fostering the development of technical skills associated with the new business. 
"Non-family managers have been hired with the intent of integrating too specific knowledge and skills" (Carlo Poccianti, 27-6-2016)

In the case of the Battiloro the logic of access to competences that support the new brands seems to prevail. One of the managing directors is involved full-time in developing relationships with other companies, entrepreneurial associations, financial institutions, and trade unions.

"I decided to invest in ideas, skills, creativity ... I am member of more than a dozen Boards of industrial and financial companies... Itake care of relationships" (Niccolò Manetti, 12-4-2016)

This networking strategy favored a proactive orientation and provided fertile ground for continuously developing and sharing new ideas to create further business opportunities. However, if knowledge related to potential new brands and markets has been developed mainly thanks to a fruitful exchange with the outside, the upgrade of managerial skills has also benefited from the entrance of the younger branch of the family in the roles of governance and management. In this sense, then, the origin of the recent innovative strategies can somehow be traced back to the completion of the last generational transition. Finally, the technical competences linked to the new brands were developed internally.

In the same way, the Lanificio maintained, throughout the period of observation, its capability to acquire/access new competences, although they were not immediately employable in the new productions. In this case the ability to gather new knowledge through the interpersonal network of the current entrepreneurs appears to be balanced by the internal growth of technical capabilities, primarily based on a learning-by-doing approach. The ability to choose people with the right competences (mix of technical skills and creativity), together with the willingness to listen and learn from them, is the key to reading the company's recent development, perhaps more than any other action taken by the owners. In particular, the recruitment of a new technical designer, a key role in designing collections, has proved to be essential for the development of not only technical know-how, but also of a "winning team", thanks to a dense network of relationships with people working in the textile industry.

\section{Discussion and Conclusion}

The joint analysis of the three cases highlights some similarities but also some differences as regards the ir governance structure and the way they satisfy the need for new competences. The comparison between the cases does not lead to clear-cut and univocal results. However, this work is able to shed new light on the relationship between the composition and dynamics of the governing bodies on the one hand, and the innovation paths undertaken by firms on the other. Moreover, it suggests revisiting the assumptions of the theory about the role of the $\mathrm{BoD}$ in fostering or inhibiting innovation in family-owned SMEs. In particular, our findings question the assumption that the presence/absence of external members on the Board can foster/hinder innovation.

In the period of observation, the analyzed firms did not show any change either in number or in type (inside vs. outside) of members belonging to their respective Boards, whereas the last significant changes in the composition of the $\mathrm{BoD}$ are sufficiently distant in time to be considered at the origin of the recent decisions concerning inno vation. No external member is present initially on the Boards of the three companies and no one is included during the period. Furthermore, no other formal governing body (e.g. family councils) was set up in the same time period. This can be partially explained by the fact that in all three of the companies the last generational change occurred in the 90s and it probably exhausted its effect on the Board's composition before the turn of the new millennium.

Indeed, changes in type and composition of governing bodies do not necessarily result from a generational shift. They may also come from the entrepreneurial or managerial willingness to align the firm's strategy, go vernance, and organization. Moreover, they may result from the acknowledgement that a greater openness of the Board to external members allows the firm to gather knowledge and skills that it is not able to develop inside, on its own.

The firms show different approaches regarding both the composition of the $\mathrm{BoD}$ and the responses to the widening of the ownership base. Furthermore, all of the choices concerning the governance structure seem to diverge from prescriptions and suggestions expressed by the mainstream theory (Schwartz \& Barnes, 1991; Schulze et al., 2003). Although literature emphasizes the role of non-family members in seizing environmental opportunities, developing a better awareness of the company's challenges, and, ultimately, in fostering innovation, our analysis suggests that the different approaches to innovation are not the result of any specific choice as regards the presence of non-family members in the Board. Hence, the reluctance to open the Board to external members does not seem to preclude the implementation of innovative strategies. What is more relevant, for this purpose, seems to be the propensity to network and the resulting ability to access external competences.

Our research presents from some limitations; two, in particular, are worth noting. First of all, the limited number 
of investigated cases, due to the fact that we are still at an early stage of research, prevent us from asserting that theoretical saturation has been achieved since we do not rule out that some relevant topics may still emerge from the analysis of additional cases. Secondly, our distinction between a low, medium, and high rate of innovation finds no confirmation in the literature about family businesses. It would require a better explanation to achieve a less subjective classification and be more suitable for application in future research, especially in the case of a quantitative analysis at the organizational population level.

Nevertheless, we believe that our preliminary findings may warn against the excessive focus on the role of the governance structures in favoring or inhibiting innovative processes. Moreover, such evidence suggests that both the acquisition of knowledge through targeted hiring processes, and access to external knowledge through intense networking activities can be decisive in stimulating innovation in family SMEs.

\section{References}

Arregle, J. L., Naldi, L., Nordqvist, M., \& Hitt, M. A. (2012). Internationalization of family-controlled firms: a study of the effects of external involvement in governance. Entrepreneurship Theory and Practice, 36(6), 1115-1143. https://doi.org/10.1111/j.1540-6520.2012.00541.x

Bammens, Y., Voordeckers, W., \& Van Gils, A. (2011). Boards of directors in family businesses: A literature review and research agenda. International Journal of Management Reviews, 13(2), 134-152. https://doi.org/10.1111/j.1468-2370.2010.00289.x

Bettinelli, C. (2011). Board of directors in family firms: An exploratory study of structure and group processes. Family Business Review, 24, 151-169. https://doi.org/10.1177/0894486511402196

Blanco-Mazagatos, V., de Quevedo-Puente, E., \& Delgado-García, J. B. (2016). How agency conflict between family managers and family owners affects performance in wholly family-owned firms: A generational perspective. Journal of Family Business Strategy, 7(3), 167-177. https://doi.org/10.1016/j.jfbs.2016.07.003

Bonti, M., \& Cori, E. (2011). Organizational issues and capabilities dynamic among the Italian centenarian family SMEs: An empirical investigation. Proceedings $11^{\text {th }}$ Euram Conference, Tallinn, June.

Calabró, A., \& Mussolino, D. (2011). How do Boards of Directors Contribute to Family SMEs Export Intensity? The Role of Formal and Informal Governance Mechanisms. Journal of Management and Governance, 17(2), 363-403. https://doi.org/10.1007/s10997-011-9180-7

Calabrò, A., Mussolino, D., \& Huse, M. (2009). The role of Boards of directors in the internationalization process of small and medium sized family businesses. International Journal of Globalization and Small Business, 3(4), 393-411. https://doi.org/10.1504/IJGSB.2009.032259

Carnes, C. M., \& Ireland, R. D. (2013). Familiness and innovation: Resource bundling as the missing link. Entrepreneurship Theory and Practice, 37(6), 1399-1419. https://doi.org/10.1111/etap.12073

Carney, M. (2005). Corporate governance and competitive advantage in family-controlled firms. Entrepreneurship theory and practice, 29(3), 249-265. https://doi.org/10.1111/j.1540-6520.2005.00081.x

Chen, H. L., Hsu, W. T., \& Chang, C. Y. (2014). Family ownership, institutional ownership, and internationalization of SMEs. Journal of Small Business Management, 52(4), 771-789. https://doi.org/10.1111/jsbm.12031

Chrisman, J. J., Chua, J. H., De Massis, A., Frattini, F., \& Wright, M. (2015). The ability and willingness paradox in family firm innovation. Journal of Product Innovation Management, 23(3), 310-318. https://doi.org/10.1111/jpim.12207

Cori, E., \& Bonti, M. (2014). Handling knowledge through entrepreneurial generations: lessons from long-lived family SMEs. Piccola Impresa/Small Business, 3 .

Corsi, C., \& Prencipe, A. (2015). The Openness of Corporate Governance Structure in Small and Medium Family Firms: The Effects on Company's Internationalization. International Journal of Business and Social Science, 6(6), 29-38.

Craig, J., \& Dibrell, C. (2006). The natural environment, innovation, and firm performance: A comparative study. Family Business Review, 19(4), 275-288. https://doi.org/10.1111/j.1741-6248.2006.00075.x

Cucculelli, M., Le Breton-Miller, I., \& Miller, D. (2016). Product innovation, firm renewal and family governance. Journal of Family Business Strategy, 7, 90-104. https://doi.org/10.1016/j.jfbs.2016.02.001

Daily, C. M., Dalton, D. R., \& Cannella, A. A. (2003). Corporate governance: Decades of dialogue and data. 
Academy of management review, 28(3), 371-382. https://doi.org/10.5465/AMR.2003.10196703

De Massis, A., \& Kotlar, J. (2014). The case study method in family business research: Guidelines for qualitative scholarship. Journal of Family Business Strategy, 5, 15-29. https://doi.org/10.1016/j.jfbs.2014.01.007

De Massis, A., Chirico, F., Kotlar, J., \& Naldi, L. (2014). The temporal evolution of proactiveness in family firms: The horizontal S-curve hypothesis. Family Business Review, 27(1), 35-50. https://doi.org/10.1177/0894486513506114

De Massis, A., Kotlar, J., Campopiano, G., \& Cassia, L. (2015). The Impact of Family Involvement on SMEs' Performance: Theory and Evidence. Journal of Small Business Management, 53(4), 924-948. https://doi.org/10.1111/jsbm.12093

De Massis, A., Kotlar, J., Frattini, F., Chrisman, J. J., \& Nordqvist, M. (2016). Family Governance at Work: Organizing for New Product Development in Family SMEs. Family Business Review, 29(2), 189-213. https://doi.org/10.1177/0894486515622722

Dekker, J., Lybaert, N., Steijvers, T., \& Depaire, B. (2015). The Effect of Family Business Professionalization as a Multidimensional Construct on Firm Performance. Journal of Small Business Management, 53(2), 516-538. https://doi.org/10.1111/jsbm.12082

Eisenhardt, K. M., \& Graebner, M. E. (2007). Theory Building from Cases: Opportunities and Challenges. Academy of Management Journal, 50(1), 25-32. https://doi.org/10.5465/AMJ.2007.24160888

Eisenhardt. K. M. (1989). Building theories from case study research. Academy of Management Review, 14(4), 532-550.

Filatotchev, I., Toms, S., \& Wright, M. (2006). The firm's strategic dynamics and corporate governance

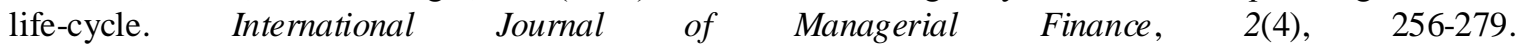
https://doi.org/10.1108/17439130610705481

Gabrielsson, J. \& Huse, M. (2005). "Outside" Directors in SME Boards: A Call for Theoretical Reflections. Corporate Board: Role, Duties \& Composition, 1, 28-38. https://doi.org/10.22495/cbvli1 art3

Gabrielsson, J., \& Winlund, H. (2000). Boards of directors in small and medium-sized industrial firms: examining the effects of the board's working style on board task performance. Entrepreneurship \& Regional Development, 12(4), 311-330. https://doi.org/10.1080/08985620050177930

Golden, B. R., \& Zajac, E. J. (2001). When will boards influence strategy? Inclination $\times$ power= strategic change. Strategic management journal, 22(12), 1087-1111. https://doi.org/10.1002/smj.202

Gómez-Mejía, L. R., Haynes, K. T., Núñez-Nickel, M., Jacobson, K. J., \& Moyano-Fuentes, J. (2007). "Socioemotional wealth and business risks in family-controlled firms: Evidence from Spanish olive oil mills. Administrative science quarterly, 52(1), 106-137. https://doi.org/10.2189/asqu.52.1.106

Gubitta, P., \& Pittino, D. (2009). Is board composition a correct predictor of firm performance in family SMEs? A test of resource dependence and resource based theory. $X$ Workshop di Organizzazione Aziendale, Cagliari, 29-30 April.

Hall, A., \& Nordqvist, M. (2008). Professional management in family businesses: Toward an extended understanding. Family Business Review, 2 1(1), 51-69. https://doi.org/10.1111/j.1741-6248.2007.00109.x

Hoskisson, R. E., Hitt, M. A., Johnson, R. A., \& Grossman, W. (2002). Conflicting voices: The effects of institutional ownership heterogeneity and internal governance on corporate innovation strategies. Academy of Management Journal, 45(4), 697-716. https://doi.org/10.2307/3069305

Huse, M. (2000). Boards of Directors in SMEs: A Re view and Research Agenda. Entrepreneurship and Regional Development, 12(4), 271-290. https://doi.org/10.1080/08985620050177912

Huse, M. (2007). Boards, governance and value creation: The human side of corporate governance, Cambridge University Press. https://doi.org/10.1017/CBO9780511611070

Istat (Italian National Institute of Statistics) (2014). Report on structure and competitiveness of the system of the industrial and services enterprises.

Jehn, K. A. (1995). A multimethod examination of the benefits and detriments of intragroup conflict. Administrative science quarterly, 256-282. https://doi.org/10.2307/2393638

Johannisson, B., \& Huse, M. (2000). Recruiting Outside Board Members in the Small Family Business: An Ideological Challenge. Entrepreneurship \& Regional Development, 12, 353-378. 
Kellermanns, F. W., \& Eddleston, K. A. (2006). Corporate entrepreneurship in family firms: A family perspective. Entrepreneurship theory and practice, 30(6), 809-830. https://doi.org/10.1111/j.1540-6520.2006.00153.x

Klein, P., Shapiro, D., \& Young, J. (2005). Corporate governance, family ownership and firm value: the Canadian evidence. Corporate Governance: An International Review, 13(6), 769-784. https://doi.org/10.1111/j.1467-8683.2005.00469.x

Kouki, M., \& Guizani, M. (2015). Outside directors and firm performance: The moderating effects of ownership and board leadership structure. International Business Research, 8(6), 104. https://doi.org/10.5539/ibr.v8n6p104

LeBreton-Miller, I., \& Miller, D. (2013). Socio-emotional wealth across the family firm life cycle: A commentary on Family Business Survival and the Role of Boards. Entrepreneurship Theory and Practice, 37(6), 1391-1397. https://doi.org/10.1111/etap.12072

Li, Z., \& Daspit, J. J., (2016). Understanding family firm innovation heterogeneity: A typology of family governance and socio-emotional wealth intentions. Journal of Family Business Management, 6(2), 103-121. https://doi.org/10.1108/JFBM-02-2015-0010

Llach, J., \& Nordqvist, M. (2010). Innovation in family and non-family businesses: A resource perspective. International Journal of Entrepreneurial Venturing, 2(3-4), 381-399. https://doi.org/10.1504/IJEV.2010.037119

Lumpkin, G. T., \& Brigham, K. H. (2011). Long-term orientation and intertemporal choice in family firms. Entrepreneurship Theory and Practice, 35(6), 1149-1169. https://doi.org/10.1111/j.1540-6520.2011.00495.x

Lynall, M. D., Golden, B. R. \& Hillman, A. J. (2003). Board composition from adolescence to maturity: A multi-theoretic view. Academy of Management Review, 28(3), 416-431. https://doi.org/10.5465/AMR.2003.10196743

Majocchi, A., \& Strange, R. (2012). International diversification: The impact of ownership structure, the market for corporate control and board independence. Management International Review, 52, 879-900. https://doi.org/10.1007/s11575-012-0148-x

Maseda, A., Iturralde, T., \& Arosa, B. (2015). Impact of Outsiders on Firm Performance over Different Generations of Family-Owned SMEs. Journal of Small Business Management, 53(4), 1203-1218. https://doi.org/10.1111/jsbm.12119

Matzler, K., Veider, V., Hautz, J., \& Stadler, C. (2015). The impact of family ownership, management and governance on innovation. Journal of Product Innovation Management, 32(3), 319-333. https://doi.org/10.1111/jpim.12202

Miller, D., \& LeBreton-Miller, I. (2005). Managing for the Long Run: Lessons in Competitive Advantage from Great Family Businesses, Harvard Business School Press, Boston.

Miller, D., \& LeBreton-Miller, I. (2006). Family governance and firm performance: Agency, stewardship, and capabilities. Family business review, 19(1), 73-87. https://doi.org/10.1111/j.1741-6248.2006.00063.x

Nordqvist, M., Sharma, P., \& Chirico, F. (2014). Family firm heterogeneity and governance: A configuration approach. Journal of Small Business Management, 52(2), 192-209. https://doi.org/10.1111/jsbm.12096

Pardo del Val, M. (2009). Succession in family firms from a multi-staged perspective. International Entrepreneurship and Management Journal, 5(2), 165-179. https://doi.org/10.1007/s11365-008-0092-1

Pauwels, P. \& Matthyssens, P. (2004). The architecture of multiple case study research in international business. Handbook of qualitative research methods for international business, 125-143. https://doi.org/10.4337/9781781954331.00020

Pieper, T. (2003). Corporate governance in family firms: A literature review. Insead.

Schulze, W. S., Lubatkin, M. H. \& Dino, R. N. (2003). Exploring the Agency Consequences of Ownership Dispersion among the Directors of Private Family Firm. Academy of Management Journal, 46(2), 179-194. https://doi.org/10.2307/30040613

Schwartz, M. A., \& Barnes, L. B. (1991). Outside boards and family businesses: Another look. Family Business Review, 4(3), 269-285. https://doi.org/10.1111/j.1741-6248.1991.00269.x

Segaro, E. (2012). Internationalization of family SMEs: the impact of ownership, governance, and top 
management team. Journal of Management \& Governance, 16(1), 147-169. https://doi.org/10.1007/s 10997-010-9145-2

Van den Heuvel, J., Van Gils, A., \& Voordeckers, W. (2006). Board Roles in Small and Medium-Sized Family Businesses: performance and importance. Corporate Governance, 14(5), 467-485. https://doi.org/10.1111/j.1467-8683.2006.00519.x

Vilaseca, A. (2002). The shareholder role in the family business: Conflict of interests and objectives between non-employed shareholders and top management team. Family Business Review, 15(4), 299-320. https://doi.org/10.1111/j.1741-6248.2002.00299.x

Voordeckers, W., Van Gils, A., \& Van den Heuvel J. (2007). Board composition in small and medium-sized family firms. Journal of Small Business Management, 45(1), 137-156. https://doi.org/10.1111/j.1540-627X.2007.00204.X

Ward, J. L. (1988). The active board with outside directors and the family firm. Family Business Review, 1(3), 223-229. https://doi.org/10.1111/j.1741-6248.1988.00223.x

Ward, J. L. (1989). Defining and researching inside versus outside directors: a rebuttal to the rebuttal. Family Business Review, 2(2), 147-150. https://doi.org/10.1111/j.1741-6248.1989.00147.x

Ward, J. L. (1997). Growing the family business: Special challenges and best practices. Family Business Review, 10(4), 323-337. https://doi.org/10.1111/j.1741-6248.1997.00323.x

Yin, R. K. (2009). Case Study Research Design and Methods, Second Edition, Thousand Oaks, CA: Sage Publications.

Zahra, S. A., \& Pearce, J. A. (1989). Boards of directors and corporate financial performance: A review and integrative model. Journal of management, 15(2), 291-334. https://doi.org/10.1177/014920638901500208

\section{Copyrights}

Copyright for this article is retained by the author(s), with first publication rights granted to the journal.

This is an open-access article distributed under the terms and conditions of the Creative Commons Attribution license (http://creativecommons.org/licenses/by/4.0/). 